\title{
Soil organic carbon along an altitudinal gradient in the Despeñaperros Natural Park, southern Spain
}

\author{
L. Parras-Alcántara, B. Lozano-García, and A. Galán-Espejo
}

Department of Agricultural Chemistry and Soil Science, Faculty of Science, Agrifood Campus of International Excellence ceiA3, University of Córdoba, 14071 Córdoba, Spain

Correspondence to: L. Parras-Alcántara (qe1paall@uco.es)

Received: 5 August 2014 - Published in Solid Earth Discuss.: 21 August 2014

Revised: 14 December 2014 - Accepted: 22 December 2014 - Published: 3 February 2015

\begin{abstract}
Soil organic carbon (SOC) is extremely important in the global carbon (C) cycle as $\mathrm{C}$ sequestration in non-disturbed soil ecosystems can be a $\mathrm{C}$ sink and mitigate greenhouse-gas-driven climate change. Soil organic carbon changes in space and time are relevant to understand the soil system and its role in the $\mathrm{C}$ cycle. This is why the influence of topographic position on SOC should be studied. Seven topographic positions from a toposequence between 607 and $1168 \mathrm{~m}$ were analyzed in the Despeñaperros Natural Park (Jaén, SW Spain). Depending on soil depth, one to three control sections $(0-25,25-50$ and $75 \mathrm{~cm})$ were sampled at each site. The SOC content in studied soils was below $30 \mathrm{~g} \mathrm{~kg}^{-1}$ and strongly decreases with depth. These results were related to the gravel content and to the bulk density. The SOC content from the topsoil $(0-25 \mathrm{~cm})$ varied largely through the altitudinal gradient ranging between 27.3 and $39.9 \mathrm{~g} \mathrm{~kg}^{-1}$. The SOC stock (SOCS) varied between 53.8 and $158.0 \mathrm{Mg} \mathrm{ha}^{-1}$ in the studied area, which had been clearly conditioned by the topographic position. Therefore, results suggest that elevation should be included in SOCS models and estimations at local and regional scales.
\end{abstract}

\section{Introduction}

Soils are an important carbon reservoir (Barua and Haque, 2013; Yan-Gui et al., 2013). In fact, the primary terrestrial pool of organic carbon (OC) is soil, which accounts for more than $71 \%$ of the Earth's terrestrial OC pool (Lal, 2010). In addition, soils have the ability to store $\mathrm{C}$ for a long time (over the last 5000 years) (Brevik and Homburg, 2004). Soils play a crucial role in the overall $\mathrm{C}$ cycle, and small changes in the soil organic carbon stock (SOCS) could significantly affect atmospheric carbon dioxide $\left(\mathrm{CO}_{2}\right)$ concentrations, and through that global climate change. Within the $\mathrm{C}$ cycle, soils can be a source of greenhouse gases through $\mathrm{CO}_{2}$ and methane $\left(\mathrm{CH}_{4}\right)$ emissions, or can be a sink for atmospheric $\mathrm{CO}_{2}$ through $\mathrm{C}$ sequestration in soil organic matter (OM) (Breuning-Madsen et al., 2009; Brevik, 2012).

Climate, soil use and soil management affect OC variability, particularly in soils under Mediterranean type of climate, characterized by low OC content, weak structure and readily degradable soils (Hernanz et al., 2002). In temperate climates, recent studies show differences in $\mathrm{C}$ sequestration rates in soils depending on use and management (MuñozRojas et al., 2012a, b), climate and mineralogical composition (Wang et al., 2010), texture, slope and elevation (Hontoria et al., 2004), and tillage intensity and no-till duration (Umakant et al., 2010). Soil conservation strategies are being seen as a strategy to increase soil OM content (Barbera et al., 2012; Batjes et al., 2014; Jaiarree et al., 2014; Srinivasarao et al., 2014; Fialho and Zinn, 2014).

Several studies have been carried out to estimate differences in soil organic carbon (SOC) dynamics in relation to soil properties, land uses and climate (Eshetu et al., 2004; Lemenih and Itanna, 2004; Muñoz-Rojas et al., 2013). Although the impact of topographic position on soil properties on SOC content is widely recognized (Venterea et al., 2003; Fu et al., 2004; Brevik, 2013), relatively few studies have been conducted to examine the role of topographic position (Fernández-Romero et al., 2014; Lozano-García et al., 2014).

The spatial variation of soil properties may also be significantly influenced by aspect (which may induce microclimate variations), physiography, parent material, and 
vegetation (López-Vicente et al., 2009; Brevik, 2013; Ashley et al., 2014; Bakhshandeh et al., 2014; Dingil et al., 2014; Gebrelibanos et al., 2014; Kirkpatrick et al., 2014). Ovales and Collins (1986) evaluated soil variability due to pedogenic processes across landscapes in contrasting climatic environments and concluded that topographic position and variations in soil properties were significantly related. McKenzie and Austin (1993) and Gessler et al. (2000) found that variations of some soil properties could be related to the slope steepness, length, curvature and the relative location within a toposequence. Both studies suggest that the assessment of the hillslope sequence helps to understand variations of soil properties in order to establish relationships among specific topographic positions and soil properties. Asadi et al. (2012) found that the integrated effect of topography and land use determined soil properties. Topography is a relevant factor controlling soil erosion processes through the redistribution of soil particles and soil OM (Cerdà and García Fayos, 1997; Ziadat and Taimeh, 2013).

The topographic factor has been traditionally included in the study of the spatial distribution of soil properties (Fernández-Calviño et al., 2013; Haregeweyn et al., 2013; Ozgoz et al., 2013; Wang and Shao, 2013). Over time, many researchers have quantified the relationships between topographic parameters and soil properties such as soil OM and physical properties such as particle size distribution, bulk density and depth to specific horizon boundaries (McKenzie and Austin, 1993; Gessler et al., 1995, 2000; Pachepsky et al., 2001; Ziadat, 2005). Soil OM content has been negatively correlated with the topographic gradient (Ruhe and Walker, 1968) and slope gradient (Nizeyimana and Bicki, 1992). However, quantitative relationships between soil topography and soil physical-chemical properties are not well established for a wide range of environments (Hattar et al., 2010).

Research along altitudinal gradients has shed light on the effects of climate on soil properties. Ruiz-Sinoga et al. (2012) found a strong relationship between soil OM and elevation, which was due to reduced decomposition rates with lower temperatures. High erosion rates have been found under dry climates and low altitudes in Israel (Cerdà, 1998a, b), which support the idea of high OM losses due to soil erosion in dry areas.

In line with this, in Mediterranean natural areas there is no information about the soil variability; also little data is available related to the control topography exerts on soil properties (Lozano-García and Parras-Alcántara, 2014). Therefore, the aims of this study are (i) to quantify SOC contents and their vertical distribution in a natural forest area, (ii) to assess the SOCS differences in soils along an altitudinal gradient and (iii) to assess their relationship with soil depth in a Mediterranean natural area.

\section{Material and methods}

\subsection{Study site}

The Despeñaperros Natural Park $\left(76.8 \mathrm{~km}^{2}\right)$ is one of the best-preserved landscapes in southern Europe. It is located within the eastern Sierra Morena (province of Jaén, southeastern Spain), at coordinates $38^{\circ} 20^{\prime}-38^{\circ} 27^{\prime} \mathrm{N}, 3^{\circ} 27^{\prime}-$ $3^{\circ} 37^{\prime} \mathrm{W}$. The study area is characterized by warm dry summers and cool humid winters, and climate is temperate semiarid with continental features due to elevation. Average extreme temperatures range between $-10^{\circ} \mathrm{C}$ (winter) and $42^{\circ} \mathrm{C}$ (summer), with mean temperature $15^{\circ} \mathrm{C}$. The moisture regime is dry Mediterranean, with average annual rainfall of $800 \mathrm{~mm}$. High temperatures and long drought periods cause water deficits up to $350 \mathrm{~mm}$ annually.

It is a mountainous area, with an altitudinal range of $540 \mathrm{~m}$ a.s.l. in the Despeñaperros River valley to $1250 \mathrm{~m}$ a.s.l at Malabrigo Mountain. The relief is steep with slopes ranging from 3 to $45 \%$, and the parent materials are primarily slate and quartzite. Most abundant soils in the area are Phaeozems (PH), Cambisols (CM), Regosols (RG) and Leptosols (LP), according to the classification by IUSS Working Group WRB (2006) (Table 1). Well-preserved Mediterranean woodlands and scrublands occupy the study area and deer hunting habitat is the main land use.

\subsection{Soil sampling and analytical methods}

Seven sites were selected along a topographic gradient in a south-facing slope in the Despeñaperros Natural Park (Table 1). Soil samples were collected at each site following a random sampling design according to FAO (2006). Each selected point was sampled using soil control sections (SCSs) at different depths (S1: 0-25, S2: 25-50 and S3: 50-75 cm). Soil control sections were used for a uniform comparison between studied soils. Four replicates of each soil sample were analyzed in laboratory (17 sampling points $\times 1,2$ or $3 \mathrm{SCS} \times 4$ replicates).

Soil samples were air-dried at constant room temperature $\left(25^{\circ} \mathrm{C}\right)$ and sieved $(2 \mathrm{~mm})$ to discard coarse particles. The analytical methods used in this study are described in Table 2.

Statistical analysis was performed using SPSS Inc. (2004). The physical and chemical soil properties were analyzed statistically for each SCS of different soil groups (PH, CM, RG and LP), including the average and standard deviation (SD). The statistical significance of the differences in each variable between each sampling point and soil type was tested using the Anderson-Darling test at each control section for each soil type. Differences with $p<0.05$ were considered statistically significant. 
Table 1. Soil groups of the study area at each of the seven topographic positions with properties. The key refers to the reference soil groups of the IUSS Working Group WRB (2006) with lists of qualifiers.

\begin{tabular}{|c|c|c|c|c|c|c|c|c|}
\hline $\begin{array}{l}\text { Topographic } \\
\text { position }\end{array}$ & ma.s.l. ${ }^{\mathrm{a}}$ & $\begin{array}{l}\text { Slope } \\
\%\end{array}$ & $\begin{array}{l}\text { Parent } \\
\text { material }\end{array}$ & & $\begin{array}{l}\text { Vegetation } \\
\text { series }\end{array}$ & Soil groups & Qualifiers & $n^{\mathrm{b}}$ \\
\hline A & 1168 & 15.3 & $\begin{array}{l}\text { Quartzite } \\
\text { sandstone }\end{array}$ & - & $\begin{array}{l}\text { Maritime pine (Pinus pinaster) } \\
\text { Holm oak (Quercus ilex) } \\
\text { Gum rockrose (Cistus ladanifer) }\end{array}$ & Leptosols - LP & Mollic - mo & 2 \\
\hline B & 1009 & 16.5 & $\begin{array}{l}\text { Quartzite } \\
\text { sandstone }\end{array}$ & - & $\begin{array}{l}\text { Holm oak (Quercus ilex) } \\
\text { Cork oak (Quercus suber) } \\
\text { Strawberry tree (Arbutus unedo) } \\
\text { Gum rockrose (Cistus ladanifer) }\end{array}$ & $\begin{array}{l}\text { Regosols - RG } \\
\text { Leptosols - LP } \\
\text { Cambisols - CM }\end{array}$ & $\begin{array}{l}\text { Eutric - eu } \\
\text { Mollic - mo } \\
\text { Humic - hu }\end{array}$ & 3 \\
\hline $\mathrm{C}$ & 945 & 20.8 & $\begin{array}{l}\text { Quartzite } \\
\text { sandstone }\end{array}$ & - & $\begin{array}{l}\text { Stone pine (Pinus pinea) } \\
\text { Mastic (Pistacia lentiscus) }\end{array}$ & $\begin{array}{l}\text { Cambisols - CM } \\
\text { Regosols - RG } \\
\text { Phaeozems - PH }\end{array}$ & $\begin{array}{l}\text { Humic - hu } \\
\text { Dystric - dy } \\
\text { Luvic - lv }\end{array}$ & 3 \\
\hline $\mathrm{D}$ & 865 & & Quartzite & & $\begin{array}{l}\text { Portuguese oak } \\
\text { (Quercus faginea) } \\
\text { Strawberry tree (Arbutus unedo) } \\
\text { Gum rockrose (Cistus ladanifer) }\end{array}$ & Regosols - RG & Umbric - um & 2 \\
\hline $\mathrm{E}$ & 778 & & $\begin{array}{l}\text { Quartzite } \\
\text { slates }\end{array}$ & - & $\begin{array}{l}\text { Holm oak (Quercus ilex) } \\
\text { Strawberry tree (Arbutus unedo) } \\
\text { Gum rockrose (Cistus ladanifer) }\end{array}$ & Leptosols - LP & Umbric - um & 3 \\
\hline $\mathrm{F}$ & 695 & 12.0 & Quartzite & & $\begin{array}{l}\text { Cork oak (Quercus suber) } \\
\text { Holm oak (Quercus ilex) } \\
\text { Strawberry tree (Arbutus unedo) } \\
\text { Gum rockrose (Cistus ladanifer) }\end{array}$ & Leptosols - LP & Lithic - li & 2 \\
\hline $\mathrm{G}$ & 607 & 18.5 & Slates & & $\begin{array}{l}\text { Holm oak (Quercus ilex) } \\
\text { Mastic (Pistacia lentiscus) }\end{array}$ & Leptosols - LP & Mollic-mo & 2 \\
\hline
\end{tabular}

${ }^{a}$ Meters above sea level; ${ }^{b}$ sample size.

Table 2. Methods used in field measurements, laboratory analysis and to make calculations from study data.

\begin{tabular}{|c|c|}
\hline Parameters & Method \\
\hline \multicolumn{2}{|l|}{ Field measurements } \\
\hline Bulk density $\left(\mathrm{Mg} \mathrm{m}^{-3}\right)$ & Cylindrical core sampler ${ }^{\mathrm{a}}$; Blake and Hartge (1986) \\
\hline \multicolumn{2}{|l|}{ Laboratory analysis } \\
\hline Particle size distribution & Robinson pipette method; USDA (2004) ${ }^{\mathrm{b}}$ \\
\hline $\mathrm{pH}-\mathrm{H}_{2} \mathrm{O}$ & Volumetric with Bernard calcimeter; Duchaufour (1975) \\
\hline Organic C $(\%)$ & Walkley and Black method; Nelson and Sommers (1982) \\
\hline \multicolumn{2}{|c|}{ Parameters calculated from study data } \\
\hline SOC stock $\left(\mathrm{Mg} \mathrm{ha}^{-1}\right)$ & $\left(\text { SOC concentration } \times \mathrm{BD} \times d \times\left(1-\delta_{2} \mathrm{~mm} \%\right) \times 0.1\right)^{\mathrm{c}} ;$ IPCC $(2003)$ \\
\hline Total SOC stock $\left(\mathrm{Mg} \mathrm{ha}^{-1}\right)$ & $\Sigma_{\text {horizon }}$ SOC Stock horizon $;$ IPCC (2003) \\
\hline
\end{tabular}

a $3 \mathrm{~cm}$ diameter, $10 \mathrm{~cm}$ length and $70.65 \mathrm{~cm}^{3}$ volume. ${ }^{\mathrm{b}}$ Prior to determining the particle size distribution, samples were treated with $\mathrm{H}_{2} \mathrm{O}_{2}(6 \%)$ to remove organic matter (OM). Particles larger than $2 \mathrm{~mm}$ were determined by wet sieving and smaller particles were classified according to USDA standards (2004). ${ }^{\mathrm{c}}$ Where SOC is the organic carbon content $\left(\mathrm{g} \mathrm{Kg}^{-1}\right), d$ the thickness of the soil layer $(\mathrm{cm}), \delta 2 \mathrm{~mm}$ is the fractional percentage $(\%)$ of soil mineral particles $>2 \mathrm{~mm}$ in size in the soil, and BD the soil bulk density $\left(\mathrm{Mg} \mathrm{m}^{-3}\right)$.

\section{Results and discussion}

\subsection{Soil properties}

The soils are stony soils, acidic, with low base concentrations, oligotrophic and with slightly unsaturated complex change and located in areas of variable slopes ranging between 5 and $38 \%$. Phaeozems are the most developed soils in the study area. They are deep, dark, and well humidified with high biological activity and high vegetation density on gentle slopes and shady side foothills. Cambisols are developed and deep soils; however, Leptosols are the least developed and shallowest soils.

Phaeozems are the most pedogenically developed soils in the study area. They are found on gentle slopes $(<3 \%)$, 
Table 3. Properties of the soils evaluated (average $\pm \mathrm{SD}^{*}$ ) in the Despeñaperros Natural Park.

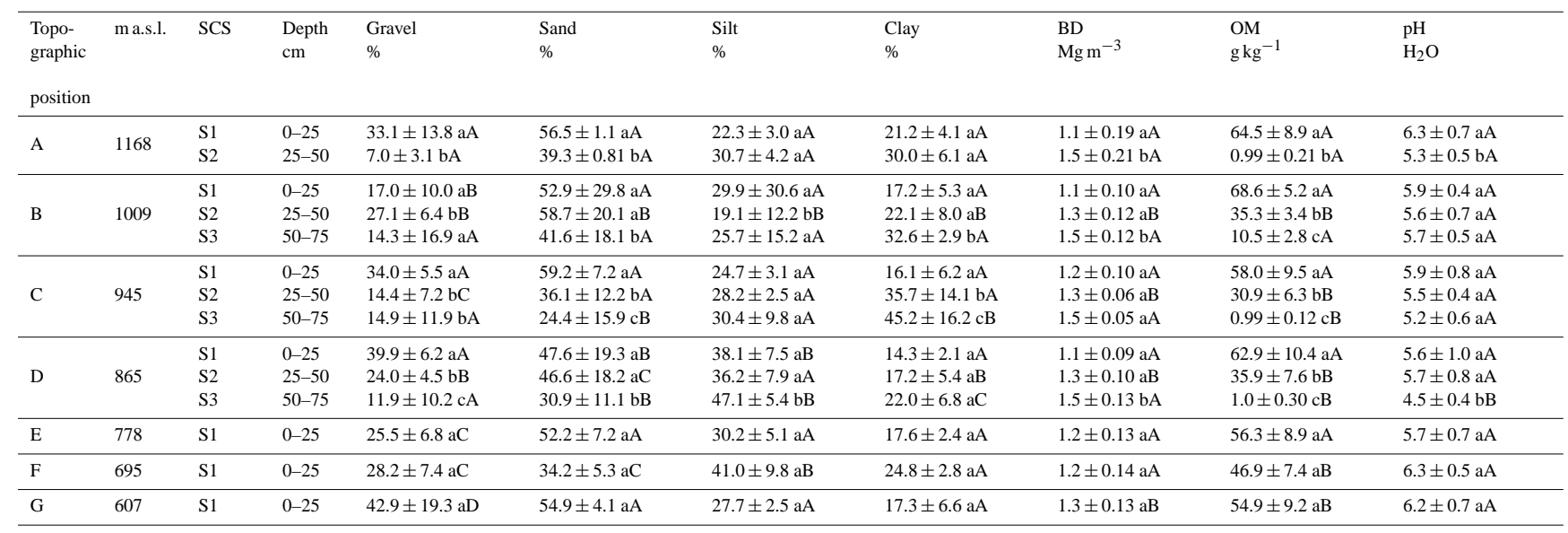

ma.s.l.: meters above sea level; SCS: soil control section; BD: bulk density; OM: organic matter. ${ }^{*}$ Standard deviation. Numbers followed by different lower-case letters within the same column have significant differences $(P<0.05)$ at different depths, considering the same topographic position. Numbers followed by different capital letters within the same column have significant differences $(P<0.05)$ considering the same SCS at different topographic positions.

usually in shaded areas on Ordovician sandstones. The gravel content is variable, ranging between 7 and $31 \%$ (total weight). Texturally they are sandy soils at the surface and silty-clay-loam or silty-clay soils at depth, with a horizon sequence A0/A1/AB/Bt/C1. These soils show Luvic (lv) characteristics (Luvic Phaeozems (lv-PH)) and are $>1 \mathrm{~m}$ in depth with $\mathrm{pH}$ along the profile ranging from 6.3 to 5.6 at depth and about $4.3 \%$ OM content (Tables 1 and 3 ).

Cambisols are less developed soils than Luvic Phaeozems; however, these soils are more developed and deeper than Regosols and Leptosols. They appear in areas of variable slope $(3-38 \%)$ and are $>1 \mathrm{~m}$ in depth characterized by a cambic horizon $(\mathrm{Bw})$ on Ordovician quartzite (Table 1) with approximately $20 \%$ gravel content. At the surface they are sandy soils $(<60 \%$ sand content) with high clay content in the Bw horizon and increasing clay content with depth (Table 3). The horizon sequences were $\mathrm{A} 0 / \mathrm{A} 1 / \mathrm{AB} / \mathrm{BW} / \mathrm{BC} / \mathrm{C} 1$ or $\mathrm{A} 0 / \mathrm{A} 1 / \mathrm{AB} / \mathrm{BW}$. These soils are characterized by low OM content at depth. Gallardo et al. (2000) showed that the low OM content could be explained by the semiarid Mediterranean conditions. In addition, Parras-Alcántara et al. (2013a) found there is less OM and fewer mineral aggregates in sandy soils, thus favoring high levels of OM transformation. Because of this, Hontoria et al. (2004) suggested that physical variables determine soil development in the driest areas of Spain to a greater degree than management or climatic variables. The Cambisols topsoil has humic (hu) characteristics, with $>5 \%$ OM content (Table 3 ) due to plant debris accumulation in the $\mathrm{A} 0$ horizon. This $\mathrm{OM}$ is poorly structured and partially decomposed, thereby reducing the amount and increasing the OM evolution degree with depth. In line with this, Bech et al. (1983) reported that the free OM concentration in the surface horizon was higher than $90 \%$, while humic and fulvic acid concentrations were less than $2 \%$ in soils with Quercus ilex spp. ballota vegetation. Free
OM was reduced and humidification increased up to $30 \%$ in deeper layers.

Regosols can be found in steeply sloping areas (>8\%) characterized by high water erosion and subject to rejuvenation processes. We found Eutric (eu), Dystric (dy) and Umbric (um) Regosols (Table 1) on sandstone and quartzite parent materials with $>25 \%$ gravel content in surface layers that in some cases disappeared in depth. These soils are sandy loam in surface layers and silty clay in deep layers, with different horizon sequences (A0/A1/AB/BC/C1, $\mathrm{A} 0 / \mathrm{A} 1 / \mathrm{AC} / \mathrm{C} 1$ and $\mathrm{A} 1 / \mathrm{AC} / \mathrm{C} 1)$. Eutric Regosols are deeper soils $(>80 \mathrm{~cm})$ that are loamy with high gravel content $(25.1-32.2 \%)$ at the surface decreasing with deep, acidic $\mathrm{pH}$ (5.9) and high OM content (6.7\%) at the surface. The Dystric Regosols are stony soils that are shallow $(<40 \mathrm{~cm})$, loamy at the surface and sandy at depth with high gravel content ( $>40 \%$ ) at the surface, acidic pH (6.2) and high OM content $(7.3 \%)$ in the surface horizon (Table 3). The Umbric Regosols are also stony soils that are deep soils $(>70 \mathrm{~cm})$, loamy with high gravel content $(40 \%)$ in the surface decreasing to $11 \%$ at depth, have acidic $\mathrm{pH}$ (5.6) and high OM content $(6.5 \%)$ (Table 3$)$.

Leptosols are the least developed soils of the study area. Lithic (li), Mollic (mo) and Eutric (eu) Leptosols were identified (Table 1) formed in sandstone, quartzite and slate on variable slopes $(1.5-46 \%)$. Horizon sequences A1/AC/C1, $\mathrm{A} 1 / \mathrm{AC}$, and $\mathrm{AC} / \mathrm{C} 1$ and $\mathrm{A} 1$ were found. The gravel content was variable ( $>40 \%$ in the topographically elevated areas and decreasing with depth) with high sand content $(>50 \%)$ in the surface layers. One characteristic of these soils is that the clay content increased with depth, reaching up to $30 \%$. According to Recio et al. (1986), the physicalchemical properties of the soils in the study area are due to lithology, while their low edaphic development is conditioned by age. According to Nerger et al. (2007), the alteration and pedogenesis processes taking place in these soils 
Table 4. Soil organic carbon (SOC) content and soil organic carbon stock (SOCS) (average $\pm \mathrm{SD}^{*}$ ) in the Despeñaperros Natural Park.

\begin{tabular}{|c|c|c|c|c|c|c|}
\hline $\begin{array}{l}\text { Topographic } \\
\text { position }\end{array}$ & ma.s.l. & SCS & $\begin{array}{l}\mathrm{SOC} \\
\mathrm{g} \mathrm{kg}^{-1}\end{array}$ & $\begin{array}{l}\text { T-SOC } \\
\mathrm{g} \mathrm{kg}^{-1}\end{array}$ & $\begin{array}{l}\text { SOCS } \\
\mathrm{Mgha}^{-1}\end{array}$ & $\begin{array}{l}\text { T-SOCS } \\
\mathrm{Mgha}^{-1}\end{array}$ \\
\hline A & 1168 & $\begin{array}{l}\mathrm{S} 1 \\
\mathrm{~S} 2\end{array}$ & $\begin{array}{l}37.5 \pm 16.8 \mathrm{aA} \\
0.58 \pm 0.09 \mathrm{bA}\end{array}$ & $38.1 \pm 8.4 \mathrm{~A}$ & $\begin{array}{l}70.8 \pm 33.5 \mathrm{aA} \\
2.1 \pm 0.57 \mathrm{bA}\end{array}$ & $72.9 \pm 17.0 \mathrm{~A}$ \\
\hline B & 1009 & $\begin{array}{l}\text { S1 } \\
\text { S2 } \\
\text { S3 }\end{array}$ & $\begin{array}{l}39.9 \pm 10.3 \mathrm{aA} \\
20.5 \pm 6.4 \mathrm{bB} \\
6.1 \pm 7.8 \mathrm{cA}\end{array}$ & $66.6 \pm 8.2 \mathrm{~B}$ & $\begin{array}{l}91.1 \pm 13.2 \mathrm{aB} \\
49.8 \pm 14.9 \mathrm{bB} \\
19.1 \pm 19.2 \mathrm{cA}\end{array}$ & $158.0 \pm 15.8 \mathrm{~B}$ \\
\hline $\mathrm{C}$ & 945 & $\begin{array}{l}\text { S1 } \\
\text { S2 } \\
\text { S3 }\end{array}$ & $\begin{array}{l}33.7 \pm 8.6 \mathrm{aA} \\
18.0 \pm 9.1 \mathrm{bB} \\
0.58 \pm 0.09 \mathrm{cB}\end{array}$ & $52.3 \pm 5.9 \mathrm{C}$ & $\begin{array}{l}67.4 \pm 9.7 \mathrm{aA} \\
50.1 \pm 22.4 \mathrm{bB} \\
1.8 \pm 0.26 \mathrm{cB}\end{array}$ & $119.3 \pm 10.9 \mathrm{C}$ \\
\hline $\mathrm{D}$ & 865 & $\begin{array}{l}\text { S1 } \\
\text { S2 } \\
\text { S3 }\end{array}$ & $\begin{array}{l}36.6 \pm 7.9 \mathrm{aA} \\
20.9 \pm 9.0 \mathrm{bB} \\
0.57 \pm 0.09 \mathrm{cB}\end{array}$ & $58.1 \pm 5.7 \mathrm{C}$ & $\begin{array}{l}62.1 \pm 8.9 \mathrm{aA} \\
52.1 \pm 16.7 \mathrm{bB} \\
1.9 \pm 0.30 \mathrm{cB}\end{array}$ & $116.1 \pm 8.6 \mathrm{C}$ \\
\hline $\mathrm{E}$ & 778 & $\mathrm{~S} 1$ & $32.7 \pm 13.2 \mathrm{aA}$ & $32.7 \pm 13.2 \mathrm{~A}$ & $72.6 \pm 25.0 \mathrm{aA}$ & $72.6 \pm 0.65 \mathrm{~A}$ \\
\hline $\mathrm{F}$ & 695 & $\mathrm{~S} 1$ & $27.3 \pm 15.1 \mathrm{aB}$ & $27.3 \pm 15.1 \mathrm{~A}$ & $59.3 \pm 27.3 \mathrm{aC}$ & $59.3 \pm 27.3 \mathrm{~A}$ \\
\hline $\mathrm{G}$ & 607 & $\mathrm{~S} 1$ & $31.9 \pm 13.1 \mathrm{aB}$ & $31.9 \pm 13.1 \mathrm{~A}$ & $53.8 \pm 18.3 \mathrm{aC}$ & $53.8 \pm 18.3 \mathrm{~A}$ \\
\hline
\end{tabular}

m a.s.l.: meters above sea level; SCS: soil control section; SOC: soil organic carbon; T-SOC: total SOC; SOCS: soil organic carbon stock; T-SOCS: total SOCS. * Standard deviation. Numbers followed by different lower-case letters within the same column have significant differences $(P<0.05)$ at different depths, considering the same topographic position. Numbers followed by different capital letters within the same column have significant differences $(P<0.05)$ considering the same SCS at different topographic positions.

usually occur on low slopes. The Lithic Leptosols are the least developed soils at this study site, with thicknesses ranging between 10 and $15 \mathrm{~cm}$ in areas of steep slope. In flat areas, their low development is due to their extreme youth. These soils are loamy with a high gravel content ( $>28 \%$ ), acidic $\mathrm{pH}$ and $>4 \%$ OM content. Mollic Leptosols are characterized by mollic surface horizons (thick, well-structured, dark, high base saturation and high OM content), on variable slopes (18.5-38.5\%). According to Corral-Fernández et al. (2013) these soils are characterized by organic residue accumulation in the surface horizons; this OM is poorly structured and partially decomposed at the surface with increasing decomposition rate with depth. Umbric Leptosols are characterized by high OM content, are shallow, and either loamy with high stony content ( $>20 \%$ gravel content) or sandy (>55\% sand content), have low bulk density conditioned by the OM content, high porosity and acidic pH (Table 3 ).

\subsection{Distribution of soil organic carbon}

Generally, soils in the study area are characterized by $>3 \%$ OC content, making them part of the $45 \%$ of the mineral soils of Europe that have between 2 and $6 \%$ OC content (Rusco et al., 2001). Soil OM content decreased with depth at all topographic positions (A, B, C and D positions) (Table 4). However, this property cannot be observed in the lowest topographic positions (E, F and $\mathrm{G}$ positions) due to the low edaphic development (Umbric Leptosols, Lithic Leptosols and Mollic Leptosols) as only one SCS exists (S1: 0-25 cm) (Tables 1 and 4).

The soils in this study are characterized by high sand content at the surface (S1) varying between 59.2 and $34.2 \%$ for $\mathrm{C}$ and $\mathrm{F}$ positions respectively, and reduced sand content with depth in all studied soils (Table 3), affecting OM development. Clay content reaches $45 \%$ in C: S3. In addition, the mineral medium may play an important role in soil humidification processes, so we can explain low soil OM concentrations with depth due in part to soil texture, because soil OM tends to decrease with depth in virtually all soils, regardless of textural changes. Clays over sands induce a decrease in soil OM with depth; also, the aggregate formation between $\mathrm{OM}$ and the mineral fraction is reduced favoring high $\mathrm{OM}$ levels in sandy soils at depth (González and Candás, 2004). Furthermore, Gallardo et al. (2000) argued that the relatively low concentrations of OM in depth could be explained by the climate (Mediterranean semiarid). Similar results have been found by Corral-Fernández et al. (2013), Parras-Alcántara et al. (2014) and Lozano-García and Parras-Alcántara (2013a) in the Pedroches Valley, near the study area.

Another key issue is that the clay fraction increased with depth in the $\mathrm{B}$ and $\mathrm{C}$ positions (reaching a clay content of as high as $45 \%$ (C: S3)) and its relation with soil OM at depth $(\mathrm{S} 2: 25-50 \mathrm{~cm})$, which was characterized by high OM contents as compared to S3 (B: 2.0/0.6\%; C: 1.8/0.06\%) (Tables 3 and 4). Burke et al. (1989) and Leifeld et al. (2005) have identified high OM levels in soils with high clay content in depth indicating clay stabilization mechanisms in the 
soil. This effect can be observed in the B and C topographic positions, where an increase in clay content was observed at depth as compared to the upper horizons (B: S1-17.2\%/S2$22.1 \%$; C: S1-16.1\%/S2-35.7\%). This OM increase may be due to carbon translocation mechanisms (dissolved organic carbon), soil biological activity and/or the root depth effect (Sherstha et al., 2004).

Soil OM appears to be concentrated in the first $25 \mathrm{~cm}$ (S1), where the mineralization and immobilization C processes should be slightly active. In the surface layer (S1), $\mathrm{OM}$ was variable along the toposequence studied ranging between 39.9 and $27.3 \mathrm{~g} \mathrm{~kg}^{-1}$ at the $\mathrm{B}$ and $\mathrm{F}$ positions, respectively (Table 4). In this regard, it is important to point out that the S1 layer can reach over $60 \%$ of the total soil organic carbon (T-SOC) values documented, corresponding to $60,64.4$ and $63 \%$ for the B, C and D positions respectively as compared to the rest of the soil profile ( $\mathrm{S} 2$ or $\mathrm{S} 2+\mathrm{S} 3$ ). Batjes (1996) states that for the 0 to $100 \mathrm{~cm}$ depth approximately $50 \%$ of soil organic carbon (SOC) appears in the first $30 \mathrm{~cm}$ of the soil. Jobbágy and Jackson (2000) showed that $50 \%$ of SOC is concentrated in the first $20 \mathrm{~cm}$ in forest soils to $1 \mathrm{~m}$ depth. Civeira et al. (2012) showed that SOC in the upper $30 \mathrm{~cm}$ of soils in Argentina is much higher than in the $30-100 \mathrm{~cm}$ interval. Data provided by these authors and the results obtained in this study may be comparable because in this study we used a $75 \mathrm{~cm}$ depth and the mentioned authors used a $1 \mathrm{~m}$ depth. Furthermore, Jobbágy and Jackson (2000) indicated that changes in SOC were conditioned by vegetation type (which determines the vertical distribution of roots) and to a lesser extent the effect of climate and clay content. Despite this, climatic conditions can be a determining factor in the SOC concentrations for surface horizons, whereas clay content may be the most important element in deeper horizons; also, clay contributes to stabilize $\mathrm{OM}$ by protecting physically microbial activity and reducing $C$ outputs. This effect is important under homogeneous climate conditions (as those in the study area). At the regional-global scale, the precipitation contributes to maximize SOC and temperature accelerates mineralization process decreasing the SOC (Post et al., 1982).

Results of T-SOC analysis in the studied area did not show up great along the toposequence. T-SOC depended on the degree of development of the soil that appeared at each topographical position. The T-SOC was highest at the $\mathrm{B}\left(66.5 \mathrm{~g} \mathrm{~kg}^{-1}\right), \mathrm{D}\left(58.1 \mathrm{~g} \mathrm{~kg}^{-1}\right)$ and C $\left(52.3 \mathrm{~g} \mathrm{~kg}^{-1}\right)$ positions, corresponding to CambisolsRegosols-Leptosols, Regosols, and Phaeozems-CambisolsRegosols respectively. Leptosols showed the lowest T-SOC content with $27.3 \mathrm{~g} \mathrm{~kg}^{-1}, 31.9 \mathrm{~g} \mathrm{~kg}^{-1}, 32.7 \mathrm{~g} \mathrm{~kg}^{-1}$ and 38.1 $\mathrm{g} \mathrm{kg}^{-1}$ at the F, G, E and A topographic positions, respectively. Similarly, $>60 \%$ of SOC was concentrated in the S1 layer of deeper soils (B, C and D).

Precipitation and temperature varied through the studied toposequence, where precipitation increases and temperature decreases with increasing elevation (Parras-Alcántara et al.,
2004). T-SOC content was not affected by climatic variations, but depended on the soil development in each landscape position. Reduced T-SOC contents were observed at the lowest topographic positions, where soils were shallower. This is in agreement with Power and Schlesinger (2002), who concluded that topographic position affects T-SOC, due to low OM decomposition rates under low temperatures.

\subsection{Soil organic carbon stocks}

Soil organic carbon stocks in the study area showed a reduction with depth in all topographic positions (Table 4). This SOCS reduction along the profile is linked to OM reduction with depth, which also depends on the gravel content and the bulk density (Table 3 ).

Higher values of SOCS (up to $91.1 \mathrm{Mg} \mathrm{ha}^{-1}$ ) were found in the upper SCS at elevated topographic positions (highest value at the B position). The lowest SOCS values were found at the $\mathrm{G}$ position $\left(53.8 \mathrm{Mg} \mathrm{ha}^{-1}\right)$, the lowest site in the toposequence. This trend of decreasing SOCS with decreasing elevation is constant except at the $\mathrm{A}$ and $\mathrm{E}$ positions. Both are poorly developed soils with high OM content in the surface horizon.

In the S1 SCS, between 53.8 and $58.0 \%$ of the SOCS were found at the D and B topographic positions. This constituted 63.0 and $60.0 \%$ of T-SOC in these topographic positions. This shows that the gravel content and bulk density affects the SOCS in the surface horizons of the toposequence studied, and, therefore, SOCS decreases when SOC increases. In the most developed soil, similar SOC and SOCS concentrations (B: $60 \%$-SOC; $58 \%$ - SOCS) were observed in the S1 layer, conditioned by bulk density and gravel content. In addition, SOCS decreased in depth conditioned by reduction of gravel content and increasing bulk density. This is not in agreement with Tsui et al. (2013) and Minasny et al. (2006), who suggested a negative relation between bulk density and depth as a consequence of high OM content at the surface, linked to low clay concentrations ( $\mathrm{Li}$ et al., 2010). In this sense, we observed that high SOCS depended on the SOC concentration and the clay content. However, the SOC concentration affected the SOCS to a lesser degree so that in S2 $(25-50 \mathrm{~cm})$ we found $>10 \%$ of SOCS related to SOC (C position).

In contrast, low SOCS can be found in S3 except at the B topographic position $\left(19.1 \mathrm{Mg} \mathrm{ha}^{-1}\right)$. This situation could be due to the fact that pedological horizons were generally different than the SCS divisions (S1: 0-25 cm; S2: 25-50 and S3: $50-75 \mathrm{~cm}$ ) (Hiederer, 2009); in other words, the SCS divisions often led to the mixing of two or more soil horizons (depending on thickness horizon) in any given SCS division.

In all studied soils, the clay content increased with depth. This clay content increase is associated with higher values of SOC (B: S2 and C: S2). In line with this, we can explain high SOCS concentrations in clayey soils caused by clay stabilization mechanisms on SOC; this effect can observed at the A 


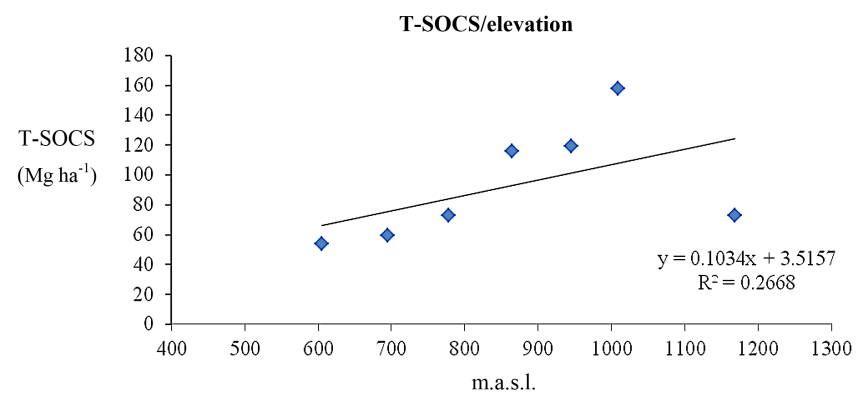

Figure 1. Exponential regression model for T-SOCS versus altitudinal gradient. T-SOCS: total soil organic carbon stock

topographic position which has higher clay content with respect to the B and D positions. However, a SOCS increase can be observed. This is the case at the $\mathrm{D}$ and $\mathrm{C}$ topographical positions with SOCS values of 52.1 and $50.1 \mathrm{Mgha}^{-1}$, respectively in the S2 sampling layer (Table 4), showing a correlation between $\mathrm{S} 1$ and $\mathrm{S} 2$, due to carbon translocation processes as dissolved organic carbon, bioturbation and/or deep rooting (Sherstha et al., 2004).

\subsection{Soil organic carbon stocks along the altitudinal gradient}

The SOCS results along the toposequence were also studied. It is important to point out that total SOCS (T-SOCS) was influenced by topographical position in the toposequence analyzed. T-SOCS increased exponentially with elevation from G (607 m a.s.l.) to B site (1009 m a.s.l.), with the exception of the highest topographic position, A (1168 ma.s.l.), with an exponential regression relationship (Fig. 1). Similar results were found by Ganuza and Almendros (2003), Leifeld et al. (2005) and Fernández-Romero et al. (2014). These studies showed that the T-SOCS increased with elevation. However, Avilés-Hernández et al. (2009) found that T-SOCS from forest soils decreased with elevation in a toposequence in Mexico due to variations in the $\mathrm{OM}$ decomposition rate, and Lozano-García and Parras-Alcántara (2014) found that T-SOCS decreased with elevation in a traditional Mediterranean olive grove due to erosion. With respect to the A position in this study, the lower T-SOCS $\left(72.9 \mathrm{Mg} \mathrm{ha}^{-1}\right)$ values with respect to the rest of the studied toposequence may be due to soil loss caused by erosion processes in soils with a low level of development. Similar results have been found by Parras-Alcántara et al. (2004) and Durán-Zuazo et al. (2013). Parras-Alcántara et al. (2004) explained their findings as a consequence of high soil erosion rates, caused by high erosivity of rainfall, high erosionability, steep slopes, low vegetation cover and the lack of conservation practices in the studied area. Durán-Zuazo et al. (2013) explained this effect by low vegetation densities in the upper parts of mountain areas that can cause high erosion with strong water runoff. Martínez-Mena et al. (2008) have emphasized the effects of erosion on soil OM loss, especially under semiarid conditions. In this context, a low vegetation cover can accelerate OM decomposition, weakening soil aggregates (Balesdent et al., 2000; Paustian et al., 2000). Cerdà (2000) indicated that this effect could occur regardless of climatic conditions.

As can be seen in Table 4, T-SOCS decrease was not homogeneous. In some cases, rapid changes were found, while in other situations gradual changes were noted. Abrupt changes in T-SOCS occurred between the B/C and D/E topographic positions, showing T-SOCS differences of $38 \mathrm{Mg} \mathrm{ha}^{-1}$ and $44 \mathrm{Mgha}^{-1}$ respectively. Gradual changes in T-SOCS occurred between the C/D, E/F and F/G topographic positions with variations of $3 \mathrm{Mg} \mathrm{ha}^{-1}, 13 \mathrm{Mg} \mathrm{ha}^{-1}$ and $6 \mathrm{Mg} \mathrm{ha}^{-1}$ respectively. Some authors have concluded that the SOCS reduction can be explained by soil physical properties - mainly texture (Corral-Fernández et al., 2013; Parras-Alcántara et al., 2013b). The studied soils are sandy at the surface, with clay increasing with depth, except in $\mathrm{E}, \mathrm{F}$ and $\mathrm{G}$ sites (soils that have S2 and/or S3 SCS); therefore, OM stabilizing mechanisms are produced, reducing the aggregate formation between SOC and mineral fraction at depth. As a result, the SOCS content is lower with sandy soils (Nieto et al., 2013). González and Candás (2004) and Parras-Alcántara et al. (2013a) obtained similar results: the first in sandy-loamy soils and the second in Mediterranean clayey soils. In addition, low SOC levels are conditioned by the climatic characteristics of southern Europe (Gallardo et al., 2000).

\section{Conclusions}

Soils found in the Despeñaperros Natural Park include Phaeozems, Cambisols, Regosols and Leptosols. Phaeozems are the deepest and most developed soils, and Leptosols are the least developed and shallowest soils. These soils are characterized by low OM content with depth due to the semiarid Mediterranean conditions and the high sand content. The studied soils are characterized by organic residue accumulation in the surface horizons.

The SOC content decreased with depth at all topographic positions and the clay fraction increased with depth. The mineral medium played an important role in soil humidification processes. In addition, the SOC in the S2 layers is characterized by high SOC values with respect to the S3 layers indicating clay stabilization mechanisms in the soil. We can explain this increase due to carbon translocation mechanisms (dissolved organic carbon), soil biological activity and/or the root depth effect.

With respect to T-SOC content, there is not a large difference between T-SOC along the toposequence. The T-SOC of these soils depends on the degree of development of the soils found at each topographic position. We can observe a T-SOC reduction at the lowest topographic positions for less developed soils and a T-SOC increase at the 
highest topographic positions in the more developed soils. SOCS in the study zone shows a reduction with depth in all topographic positions. This SOCS reduction along the profile is linked to OM and gravel content reduction and an increase in bulk density with depth. The T-SOCS increased with altitude, due to the higher turnover of organic material (plants) and the lower decomposition rate due to lower temperatures.

Acknowledgements. The authors thank to Eric C. Brevik for his contribution to improve this paper and Paulo Pereira (Handling Topical Editor) and the anonymous referees for the supportive and constructive comments that helped to improve the manuscript.

Edited by: P. Pereira

\section{References}

Asadi, H., Raeisvandi, A., Rabiei, B., and Ghadiri, H.: Effect of land use and topography on soil properties and agronomic productivity on calcareous soils of a semiarid region, Iran, Land Degrad. Develop., 23, 496-504, 2012.

Ashley, G. M., Beverly, E. J., Sikes, N. E., and Driese, S. G.: Paleosol diversity in the Olduvai Basin, Tanzania: Effects of geomorphology, parent material, depositional environment, and groundwater on soil development, Quat. Internat., 322/323, 6677, 2014.

Avilés-Hernández, V., Velázquez-Martínez, A., Ángeles-Pérez, G., Etchevers-Barra, J., De los Santos-Posadas, H., and Llandera, T.: Variación en almacenes de carbono en suelos de una toposecuencia, Agrociencia, 43, 457-464, 2009.

Bakhshandeh, S., Norouzi, M., Heidari, S., and Bakhshandeh, S.: The role of parent material on soil properties in sloping areas under tea plantation in Lahijan, Iran, Carpathian, J. Earth Environ. Sci., 9, 159-170, 2014.

Balesdent, J., Chenu, C., and Balabane, M.: Relationship of soil organic matter dynamics to physical protection and tillage, Soil Till. Res., 53, 215-230, 2000.

Barbera, V., Poma, I., Gristina, L., Novara, A., and Egli, M.: Longterm cropping systems and tillage management effects on soil organic carbon stock and steady state level of $\mathrm{C}$ sequestration rates in a semiarid environment, Land Degrad. Develop., 23, 8291, 2012.

Barua, A. K. and Haque, S. M. S.: Soil characteristics and carbon sequestration potentials of vegetation in degraded hills of Chittagong, Bangladesh, Land Degrad. Develop., 24, 63-71, 2013.

Batjes, N. H.: Total carbon and nitrogen in the soils of the world, Eur. J. Soil Sci., 47, 151-163, 1996.

Batjes, N. H.: Projected changes in soil organic carbon stocks upon adoption of recommended soil and water conservation practices in the Upper Tana River Catchment, Kenia, Land Degrad. Develop., 25, 278-287, 2014.

Bech, J., Hereter, A., and Vallejo, R.: Las tierras pardo ácidas sobre granodioritas de la zona nor-oriental del macizo del Montseny, An. Edaf. Agrob., 42, 371-393, 1983.

Blake, G. R. and Hartge, K. H.: Bulk density, in: Methods of soil analysis - Part I: Physical and mineralogical methods, edited by:
Klute, A., Agronomy Monography no. 9. ASA, SSSA, Madison WI, USA, 363-375, 1986.

Breuning-Madsen, H., Elberling, B., Balstroem, T., Holst, M., and Freudenberg, M.: A comparison of soil organic carbon stock in ancient and modern land use systems in Denmark, Eur. J. Soil Sci. 60, 55-63, 2009.

Brevik, E. C.: Soils and climate change: Gas fluxes and soil processes, Soil Horiz., 53, 12-23, 2012.

Brevik, E. C.: Forty years of soil formation in a South Georgia, USA borrow pit, Soil Horiz., 54, 20-29, 2013.

Brevik, E. C. and Homburg, J.: A 5000 year record of carbon sequestration from a coastal lagoon and wetland complex, Southern California, USA, Catena, 57, 221-232, 2004.

Burke, I., Yonker, C., Parton, W., Cole, C., Flach, K., and Schimel, D.: Texture, climate, and cultivation effects on soil organic matter content in U.S. grassland soils, Soil Sci. Soc. Am. J., 53, 800805, 1989.

Cerdà, A.: Effect of climate on surface flow along a climatological gradient in Israel. A field rainfall simulation approach, J. Arid Environ. 38, 145-159, 1998a

Cerdà, A.: Relationship between climate and soil hydrological and erosional characteristics along climatic gradients in Mediterranean limestone areas, Geomorphology, 25, 123-134, 1998 b.

Cerdà, A.: Aggregate stability against water forces under different climates on agriculture land and scrubland in southern Bolivia, Soil Till. Res., 57, 159-166, 2000.

Cerdà, A. and García-Fayos, P.: The influence of slope angle on sediment, water and seed losses on badland landscapes, Geomorphology, 18, 77-90, 1997.

Civeira, G., Irigoin, J., and Paladino, I. R.: Soil organic carbon in Pampean agroecosystems: Horizontal and vertical distribution determined by soil great group, Soil Horiz., 53, 43-49, 2012.

Corral-Fernández, R., Parras-Alcántara, L., and Lozano-García, B.: Stratification ratio of soil organic $\mathrm{C}, \mathrm{N}$ and $\mathrm{C}: \mathrm{N}$ in Mediterranean evergreen oak woodland with conventional and organic tillage, Agric. Ecosyst. Environ., 164, 252-259, 2013.

Dingil, M., Öztekin, M. E., and Şenol, S.: Definition of the physiographic units and land use capability classes of soils in mountainous areas via satellite imaging, Fresen. Environ. Bull., 23, 952-955, 2014.

Duchaufour, P. H.: Manual de Edafología, Editorial Toray-Masson, Barcelona, 1975.

Durán-Zuazo, V. H., Francia-Martínez, J. R., García-Tejero, I., and Cuadros-Tavira, S.: Implications of land-cover types for soil erosion on semiarid mountain slopes: Towards sustainable land use in problematic landscapes, Acta Ecol. Sinica, 33, 272-281, 2013.

Eshetu, Z., Giesler, R., and Högberg, P.: Historical land use affects the chemistry of forest soils in the Ethiopian highlands, Geoderma, 118, 149-165, 2004.

FAO: Guidelines for soil description. Food and Agriculture Organization of the United Nations, Rome, Italy, 2006.

Fernández-Calviño, D., Garrido-Rodríguez, B., López-Periago, J. E., Paradelo, M., and Arias-Estévez, M.: Spatial distribution of copper fractions in a vineyard soil, Land Degrad. Develop., 24, 556-563, 2013.

Fernández-Romero, M. L., Parras-Alcántara, L., and LozanoGarcía, B.: Land use change from forest to olive grove soils in a toposequence in Mediterranean areas (South of Spain), Agric. Ecosyst. Environ., 195, 1-9, 2014. 
Fialho, R. C. and Zinn, Y. L.: Changes in soil organic carbon under Eucaliptus plantations in Brazil: a comparative analysis, Land Degrad. Develop., 25, 428-437, 2014.

Fu, B. J., Liu, S. L., Ma, K. M., and Zhu, Y. G.: Relationships between soil characteristics, topography and plant diversity in a heterogeneous deciduous broad-leaved forest near Beijing, China, Plant Soil, 261, 47-54, 2004.

Gallardo, A., Rodríguez-Saucedo, J., Covelo, F., and FernándezAles, R.: Soil nitrogen heterogeneity in dehesa ecosystem, Plant Soil, 222, 71-82, 2000.

Ganuza, A. and Almendros, G.: Organic carbon storage of the Basques Country (Spain): the effect of climate, vegetation type and edaphic variables, Biol. Fert. Soils, 37, 154-162, 2003.

Gebrelibanos, T. and Assen, M.: Effects of slope aspect and vegetation types on selected soil properties in a dryland Hirmi watershed and adjacent agro-ecosystem, northern highlands of Ethiopia, Afr. J. Ecol., 52, 292-299, 2014.

Gessler, P. E., Moore, I. D., McKenzie, N. J., and Ryan, P. J.: Soillandscape modeling and spatial prediction of soil attributes. Special issue: integrating GIS and environmental modeling, Int. J. GIS, 9, 421-432, 1995.

Gessler, P. E., Chadwick, O. A., Chamran, F., Althouse, and L., Holmes, K.: Modeling soil-landscape and ecosystem properties using terrain attributes, Soil Sci. Soc. Am. J., 64, 2046-2056, 2000.

González, J. and Candás, M.: Materia orgánica de suelos bajo encinas: mineralización de carbono y nitrógeno, Invest. Agrar., 7583, 2004.

Haregeweyn, N., Poesen, J., Verstraeten, G., Govers, G., De Vente, J., Nyssen, J., Deckers, J., and Moeyersons, J.: Assessing the performance of a spatially distributed soil erosion and sediment delivery model (WATEM/SEDEM in Northern Ethiopia, Land Degrad. Develop. 24, 188-204, 2013.

Hattar, B. I., Taimeh, A. Y., and Ziadat, F. M.: Variation in soil chemical properties along toposequences in an arid region of the Levant, Catena, 83, 34-45, 2010.

Hernanz, J. T., López, R., Navarrete, T., and Sánchez-Girón, V.: Long-term effects of tillage systems and rotations on soil structural stability and organic carbon stratification in semiarid central Spain, Soil Till. Res., 66, 129-141, 2002.

Hiederer, R.: Distribution of Organic Carbon in Soil Profile Data, EUR 23980 EN, Luxembourg: Office for Official Publications of the European Communities, 126 pp., 2009.

Hontoria, C., Rodríguez-Murillo, J. C., and Saa, A.: Contenido de carbono orgánico en el suelo y factores de control en la España peninsular, Edafología, 11, 149-157, 2004.

IPCC, Intergovernmental Panel on Climate Change: Good practice guidance for land use, land use change and forestry, edited by: Penman, J., Gytarsky, M., Hiraishi, T., Krug, T., Kruger, D., Pipatti, R., Buendia, L., Miwa, K., Ngara, T., Tanabe, K., and Wagner, F., IPCC/OECD/IEA/IGES, Hayama, Japan, 2003.

IUSS Working Group WRB: World reference base for soil resources 2006, World Soil Resources Reports2nd edition, No. 103. FAO, Rome, Italy, 2006.

Jaiarree, S., Chidthaisong, A., Tangtham, N., Polprasert, C., Sarobol, E., and Tyler S. C.: Carbon Budget and sequestration potential in a sandy soil treated with compost, Land Degrad. Develop., 25, 120-129, 2014.
Jobbágy, E. G. and Jackson, R. B.: The Vertical Distribution of Soil Organic Carbon and Its Relation to Climate and Vegetation, Ecol. Appl., 10, 423-436, 2000.

Kirkpatrick, J. B., Green, K., Bridle, K. L., and Venn, S. E.: Patterns of variation in Australian alpine soils and their relationships to parent material, vegetation formation, climate and topography, Catena, 121, 186-194, 2014.

Lal, R.: Managing soils and ecosystems for mitigating anthropogenic carbon emissions and advancing global food security, Bioscience, 60, 708-721, 2010.

Leifeld, J., Bassin, S., and Fuhrer, J.: Carbon stocks in Swiss agricultural soils predicted by land use: soil characteristics and altitude, Agric. Ecosyst. Environ., 105, 255-266, 2005.

Lemenih, M. and Itanna, F.: Soil carbon stock and turnovers in various vegetation types and arable lands along an elevation gradient in southern Ethiopia, Geoderma 123, 177-188, 2004.

Li, P., Wang, Q., Endo, T., Chao, X., and Kakubari, Y.: Soil organic carbon stock is closely related to aboveground vegetation properties in cold-temperature mountainous forests, Geoderma, 154, 407-415, 2010.

López-Vicente, M., Navas, A., Machín, J.: Effect of physiographic conditions on the spatial variation of seasonal topsoil moisture in Mediterranean soils, Austr. J. Soil Res., 47, 498-507, 2009.

Lozano-García, B. and Parras-Alcántara, L.: Land use and management effects on carbon and nitrogen in Mediterranean Cambisols, Agric. Ecosyst. Environ., 179, 208-214, 2013.

Lozano-García, B. and Parras-Alcántara, L.: Variation in soil organic carbon and nitrogen stocks along a toposequence in a traditional Mediterranean olive grove, Land Degrad. Develop., 25, 297-304, 2014.

Martínez-Mena, M., López, J., Almagro, M., Boix-Fayos, C., and Albadalejo, K.: Effects of water erosion and cultivation on the soil carbon stock in a semiarid area of South-East Spain, Soil Till. Res., 99, 119-129, 2008.

McKenzie, N. J. and Austin, M. P.: A quantitative Australian approach to medium and small scale surveys based on soil stratigraphy and environmental correlation, Geoderma, 57, 329-355, 1993.

Minasny, B., McBratney, A. B., Mendonça-Santos, M. L., Odeh, I. O. A., and Guyon, B.: Prediction and digital mapping of soil carbon storage in the Lower Namoi Valley, Aust. J. Soil Res., 44, 233-244, 2006.

Muñoz-Rojas, M., Jordán, A., Zavala, L. M., De la Rosa, D., AbdElmabod, S. K., and Anaya-Romero, M.: Impact of land use and land cover changes on organic $\mathrm{C}$ stocks in Mediterranean soils (1956-2007), Land Degrad. Develop., 2012a.

Muñoz-Rojas, M., Jordán, A., Zavala, L. M., De la Rosa, D., AbdElmabod, S. K., and Anaya-Romero, M.: Organic carbon stocks in Mediterranean soil types under different land uses (Southern Spain), Solid Earth, 3, 375-386, doi:10.5194/se-3-375-2012, 2012b.

Muñoz-Rojas, M., Jordán, A., Zavala, L. M., González-Peñaloza, F. A., De la Rosa, D., Pino-Mejias, R., and Anaya-Romero, M.: Modelling soil organic carbon stocks in global change scenarios: a CarboSOIL application, Biogeosciences, 10, 8253-8268, doi:10.5194/bg-10-8253-2013, 2013.

Nelson, D. W. and Sommers, L. E.: Total carbon, organic carbon and organic matter, in: Methods of soil analysis, Part 2: Chemicaland microbiological properties, edietd by: Page, A. L., Miller, R. H., 
and Keeney, D., Agronomy monograph, vol. 9. ASA and SSSA, Madison WI, 539-579, 1982.

Nerger, R., Núñez, M. A., and Recio, J. M.: Presencia de carbonatos en suelos desarrollados sobre material granítico del Batolito de los Pedroches (Córdoba), in: Tendencias Actuales de la Ciencia del Suelo, edietd by: Jordán, A. and Bellifante, N., Universidad de Sevilla, 768-774, 2007.

Nieto, O. M., Castro, J., and Fernández-Ondoño, E.: Conventional tillage versus cover crops in relation to carbón fixation in Mediterranean olive cultivation, Plant Soil, 365, 321-335, 2013.

Nizeyimana, E. and Bicki, T. J.: Soil and soil-landscape relationships in the north central region of Rwanda, East-central Africa. Soil Sci., 153, 224-236, 1992.

Ovales, F. A. and Collins, M. E.: Soil-landscape relationships and soil variability in North Central Florida, Soil Sci. Soc. Am. J., 50, 401-408, 1986.

Ozgoz, E., Gunal, H., Acir, N., Gokmen, F., Birol, M., and Budak, M.: Soil quality and spatial variability assessment of effects in a typic Haplustall, Land Degrad. Develop., 24, 277-286, 2013.

Pachepsky, Y. A., Timlin, D. J., and Rawls, W. J.: Soil water retention as related to topographic variables, Soil Sci. Soc. Am. J., 65, 1787-1795, 2001.

Parras-Alcántara, L., Corral, L., and Gil, J.: Ordenación territorial del Parque Natural de Despeñaperros (Jaén): Criterios metodológicos, Ed. Instituto de Estudios Giennenses, Jaén, 2004.

Parras-Alcántara, L., Martín-Carrillo, M., and Lozano-García, B.: Impacts of land use change in soil carbon and nitrogen in a Mediterranean agricultural area (Southern Spain), Solid Earth, 4, 167-177, doi:10.5194/se-4-167-2013, 2013a.

Parras-Alcántara, L., Díaz-Jaimes, L., and Lozano-García, B.: Organic farming affects $\mathrm{c}$ and $\mathrm{n}$ in soils under olive groves in mediterranean areas, Land Degrad. Develop., available online in Wiley Online Library (wileyonlinelibrary.com) doi:10.1002/ldr.2231, 2013b.

Parras-Alcántara, L., Díaz-Jaimes, L., Lozano-García, B., Fernández, P., Moreno, F., and Carbonero, M.: Organic farming has little effect on carbon stock in a Mediterranean dehesa (southern Spain), Catena 113, 9-17, 2014.

Paustian, K., Six, J., Elliot, E. T., and Hunt, H. Q.: Management options for reducing $\mathrm{CO}_{2}$ emissions from agricultural soils, Biogeochemistry, 48, 147-163, 2000.

Post, W. M., Emanuel W. R., Zinke P. J., and Stangenberger, A. J.: Soil carbon pools and world life zones, Nature, 298, 156-159, 1982.

Power, J. and Schlesinger, W. H.: Relationships among soil carbon distribution and biophysical factors at nested spatial scales in rain forest of northeastern Costa Rica, Geoderma, 109, 165190, 2002.

Recio, J. M., Corral, L., and Paneque, G.: Estudio de suelos en la Comarca de los Pedroches (Córdoba.), An. Edaf. Agrob., 45, 989-1012, 1986.

Ruhe, R. V. and Walker, P. H.: Hillslope models and soil formation: I. open systems, in: Trans. Int. Congr. Soil Sci. 9th Adelaide, edited by: Holmes, J. W., 4. Elsevier, NY, 551-560, 1968.
Ruiz-Sinoga, J. D. and Diaz, A. R.: Soil degradation factors along a Mediterranean pluviometric gradient in Southern Spain, Geomorphology, 118, 359-368, 2010.

Ruiz-Sinoga, J. D., Pariente, S., Diaz, A. R., and Martínez-Murillo, F. J.: Variability of relationships between soil organic carbon and some soil properties in Mediterranean rangelands under different climatic conditions (South of Spain), Catena, 94, 17-25, 2012.

Rusco, E., Jones, R. J., and Bidoglio, G.: Organic Matter in the soils of Europe: Present status and future trends, EUR 20556 EN. JRC, Official Publications of the European Communities, Luxembourg, 2001.

Sherstha, B. M., Sitaula, B. K., Singh, B. R., and Bajracharya, R. M.: Soil organic carbon stocks in soil aggregates under different land use systems in Nepal, Nutr. Cycl. Agroecosys., 70, 201-213, 2004.

SPSS Inc.: SPSS for windows, Version 13.0. Chicago, SPSS Inc., 2004.

Srinivasarao, C. H., Venkateswarlu, B., Lal, R., Singh, A. K., Kundu, S., Vittal, K. P. R., Patel, J., and Patel, M. M.: Longterm manuring and fertilizer effects on depletion of soil organic stocks under Pearl millet-cluster vean-castor rotation in Western India, Land Degrad. Develop., 25, 173-183, 2014.

Tsui, C. C., Tsai, C. C., and Chen, Z. S.: Soil organic carbon stocks in relation to elevation gradients in volcanic ash soils of Taiwan, Geoderma, 209/210, 119-127, 2013.

Umakant, M., Ussiri, D., and Lal, R.: Tillage effects on soil organic carbon storage and dynamics in Corn Belt of Ohio USA, Soil Till. Res., 107, 88-96, 2010.

USDA: Soil survey laboratory methods manual, Soil survey investigation report no. 42, Version 4.0. USDA-NCRS, Lincoln, NE, 2004.

Venterea, R. T., Lovett, G. M., Groffman, P. M., and Schwarz, P. A.: Landscape patterns of net nitrification in a northern hardwood conifer forest, Soil Sci. Soc. Am. J., 67, 527-539, 2003.

Wang, Q., Wang, S., Xu, G., and Fan, B.: Conversion of secondary broadleaved forest into Chinese fir plantation alters litter production and potential nutrient returns, Plant Ecol., 209, 269-278, 2010.

Wang, Y. Q. and Shao, M. A.: Spatial variability of soil physical properties in a region of the loess plateau of PR China subjet to wind and water erosion, Land Degrad. Develop., 24, 296-304, 2013.

Yan-Gui, S., Xin-Rong, L., Ying-Wu, C., Zhi-Shan, Z., and Yan, L.: Carbon fixation of cyanobacterial-algal crusts after desert fixation and its implication to soil organic matter accumulation in Desert, Land Degrad. Develop., 24, 342-349, 2013.

Ziadat, F. M.: Analyzing digital terrain attributes to predict soil attributes for a relatively large area, Soil Sci. Soc. Am. J., 69, 1590-1599, 2005.

Ziadat, F. M. and Taimeh, A. Y.: Effect of rainfall intensity, slope and land use and antecedent soil moisture on soil erosion in an arid environment, Land Degrad. Develop., 24, 582-590, 2013. 